\title{
THE VIRTUAL WATER FLOW OF CROPS IN SEMIARID CEARÁ, BRAZIL: THE IMPACTS ON THE STATE'S WATER RESOURCES MANAGEMENT
}

\author{
SÉRGIO RODRIGUES ROCHA ${ }^{1}$, TICIANA DE CARVALHO STUDART², MARIA MANUELA PORTELA ${ }^{3}$, \\ MARTINA ZELENAKOVA ${ }^{4} \&$ ROGÉRIO SOLIANI STUDART FILHO 5 \\ ${ }^{1}$ Central Bank of Brazil \\ ${ }^{2} \mathrm{UFC}$, Brazil \\ ${ }^{3}$ IST/UL, CERIS, Portugal \\ ${ }^{4}$ TUKE, Slovakia \\ ${ }^{5}$ NOVA, Portugal
}

\begin{abstract}
Global markets foster economic growth, but production of traded goods also impacts water resource use. This is especially true for semiarid regions, given that increasing agricultural exports is a crucial pro-poor development strategy. The aim of this paper is to quantify the contribution of agricultural trade in terms of virtual water flows - blue, green and grey - between the state of Ceará-Brazil and its international partners from 1997 to 2012 and to analyse its impacts in the state's water resources policy. Essentially, all virtual water exported and imported by Ceará in agricultural products came from cashew nuts and wheat, corresponding in both cases up to $72 \%$ of green water. Interestingly, virtual green water has an important role in production but has been underestimated in the state's water resources management model, which despite successful focuses exclusively on blue water. The results show that the commercial balance of the total virtual water was always negative, meaning that Ceará imported more virtual water than it exported; this outcome is aligned with its water-scarce condition.
\end{abstract}

Keywords: agricultural international trade, Ceará, semiarid Brazil, virtual water, water footprint.

\section{INTRODUCTION}

The concept of virtual water established by Allan [1] refers to the water used in the production of any commodity. Taking a step further, Hoekstra and Hung [2] introduced the concept of the water footprint, which is the cumulative virtual water content of all goods and services consumed by one individual or by the individuals of one country. From a water resource perspective, international trade is seen today as a means of exchanging water between the world's regions [3].

The crop products contributes $76 \%$ to the total volume of international virtual water flows, whereas trade in animal and industrial products contribute 12\% each [4]. Given this disparity in volume, virtual water flow of global agricultural trade is attracting increasing attention in the literature. Food-exporting countries are, in practice, virtual water sources.

In most arid and semiarid countries, water resources management is an issue as important as controversial. Virtual water and water footprint approaches may provide an appropriate framework to find potential solutions and contribute to a better management of water resources [5]. Such analysis can identify more efficient practices and help substantiate decisions about what to produce and what to import, incorporating the virtual water concept into the region's water resources planning and management.

Located in the Brazilian semiarid region, Ceará is a state with low water availability due to a combination of many factors (Fig. 1). Among these are low precipitation (below $900 \mathrm{~mm} / \mathrm{y}$ ), high evaporation (above 2,000 mm/y), irregular rainfall (recurrent and sometimes multiannual droughts), and an unfavourable hydrogeological context ( $80 \%$ of the territory is located 


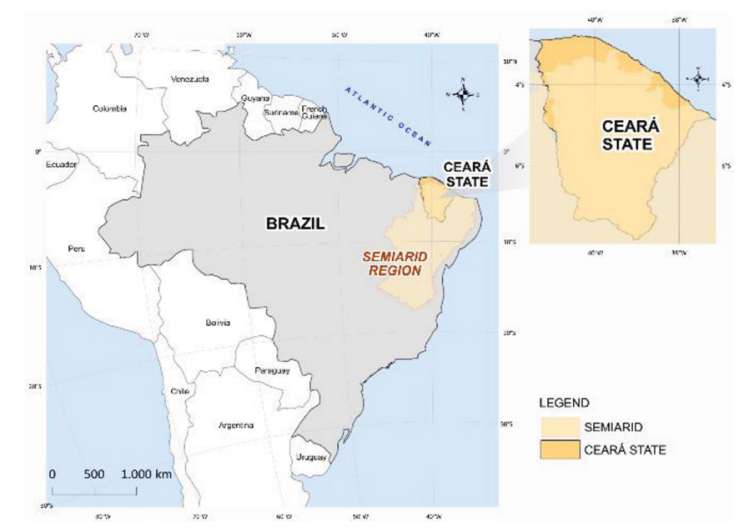

Figure 1: Location of Ceará State and the Brazilian Semiarid Region.

on crystalline rock, with a shallow soil layer and scarce underground water resources). Thus, most rivers are naturally intermittent.

The aim of this paper is to quantify the virtual water flows between Ceará and its international partners by analysing the annual commercial balance of the state's agricultural products. The quantification of its three components (blue, green and grey), considering agricultural product imports and exports from the state of Ceará, may help identify solutions to improve water management and may suggest what to produce and what to import.

\section{DATA AND METHODS}

\subsection{Data}

Through this study, the information about the agricultural products in Ceará, quantities exported and imported $(\mathrm{kg}$ ) and monetary values (US\$) were extracted from the bulletin of Ministry of Development, Industry and Foreign Trade during the period 1997-2012 [6]. Agricultural exports and imports account for a significant share of Ceará's total export and import basket are shown in Table 1. Table 2 identifies the sources from which the data on productivity of the crops harvested and climatological data of the Ceará's municipalities were taken.

\subsection{Virtual water accounting}

The productivity of the annual cycle crops was based on official agricultural production statistics, considering the average annual productivity over the full crop cycle. In the current study, the average annual productivity of each crop was calculated for the 16 study years (1997-2012). For the permanent crops, it was necessary to consider that the productivity in the first year of planting is low, or virtually null, increases after a few years, and decreases when the crop cycle ends. To quantify the water consumption of a permanent crop, it is necessary to determine its annual average water utilization over its full life cycle [7].

The data on crop coefficients and dates of planting and harvest in the study's 16-year period were investigated at EMBRAPA and EMATERCE. Based on these data, annual averages were calculated for each municipality and crop and used in the annual water footprint calculations. 
Table 1: Ceará's export and import agriculture products (1997-2012).

\begin{tabular}{|c|c|c|c|}
\hline Exported product & $\begin{array}{l}\text { Quantity } \\
\text { (t) }\end{array}$ & $10^{6} \mathrm{US} \$$ & $\%$ of total export \\
\hline Fresh or dried pineapple & $111,841.8$ & 52.7 & 0.39 \\
\hline Fresh or dried banana & $113,023.7$ & 45.5 & 0.33 \\
\hline Banana, fresh or dried, other than plantain & $22,233.5$ & 9.8 & 0.07 \\
\hline Cashew nuts, fresh or dried, shelled & $463,251.4$ & $2,228.7$ & 16.37 \\
\hline Fresh or dried mango & $29,244.8$ & 19.8 & 0.15 \\
\hline Fresh papaya & $5,256.3$ & 4.2 & 0.03 \\
\hline Fresh watermelon & $142,852.8$ & 62.3 & 0.46 \\
\hline Fresh melon & $876,643.9$ & 559.8 & 4.11 \\
\hline Total & & $2,982.8$ & 21.91 \\
\hline Imported product & $\begin{array}{l}\text { Quantity } \\
(\mathrm{t})\end{array}$ & $10^{6} \mathrm{US} \$$ & $\%$ of total import \\
\hline Cotton, threshed, not carded or combed & 261.2 & 393.3 & 2.15 \\
\hline Cotton, unthreshed, not carded or combed & 15.1 & 25.3 & 0.14 \\
\hline Cotton (other types), not carded or combed & 497.9 & 649.2 & 3.55 \\
\hline Semimilled rice, etc., not parboiled, polished, burnished & 140,0 & 57.4 & 0.31 \\
\hline Semimilled rice, etc., parboiled, polished or burnished & 11.2 & 4.3 & 0.02 \\
\hline Cashew nuts, fresh or dried, in shell & 129.7 & 136.2 & 0.75 \\
\hline Dried coconut, shelled, grated or not & 11.6 & 18.8 & 0.10 \\
\hline Maize grain, other than for sowing & 703,0 & 72.6 & 0.40 \\
\hline Durum wheat, other than for sowing & 26.5 & 6.7 & 0.04 \\
\hline Wheat (other than durum or sowing wheat) and wheat with rye & $10,776.7$ & $1,899.8$ & 10.4 \\
\hline Other wheats and mixtures of wheat and rye, other than for sowing & 852.1 & 223.8 & 1.23 \\
\hline Other common beans, black, dried, in grains & 8.0 & 5.0 & 0.03 \\
\hline Total & & $3,492.5$ & 19.12 \\
\hline
\end{tabular}

Source: [6].

Table 2: Sources of the crops produced and climatological data of the municipalities in Ceará.

\begin{tabular}{cc}
\hline Institution & \\
\hline Ministry of Development, Industry and Foreign Trade & MDIC, Brazil \\
AgroStat System of Foreign Trade Statistics of Brazilian & MAPA, Brazil \\
Agribusiness of the Ministry of Agriculture, Livestock and Supply & National Supply Company \\
Brazilian Agricultural Research Company & EMBRAPA, Brazil \\
Brazilian Institute of Geography and Statistics & IBGE, Brazil \\
Secretariat of Agrarian Development of the State of Ceará & SDA, Ceará \\
Technical Assistance and Rural Extension Company of Ceará & EMATERCE, Ceará \\
Institute of Economic Research and Strategy of Ceará & IPECE, Ceará \\
National Institute of Meteorology & INMET, Brazil \\
Development Agency of the State of Ceará & ADECE, Ceará \\
Agricultural Defense Agency of the State of Ceará & ADAGR, Ceará \\
Foundation for Meteorology and Water Resources of Ceará & FUNCEME, Ceará \\
\hline
\end{tabular}

The exported products' water footprint was calculated according to production approach [8], which quantifies virtual water as being consumed at the place of the commodity's production that is, for the case study, in Ceará.

Due to the great heterogeneity of climate and soil, the productivity of a given crop is not the same for the whole state. Thus, for each exported crop, the municipality with the highest 
production (in kilograms) in the studied period was selected. The type of exported crop and the method for meeting its water needs were selected based on which were predominant in the municipality with the highest production for that crop.

The imported products' water footprint was calculated according to the consumption approach [8], which refers to the volume of water that would have been necessary to produce the commodity in the place where it is consumed, that is, in Ceará. Table 3 identifies each exported and imported crop by municipality of Ceará state, considering the highest production for the period, the type of agriculture used, and the water supply method applied for the particular crop.

The crop productivity, crop planting and harvesting period, application rate of fertilizer, pesticides and insecticides per unit area of product, crop coefficient, reference evapotranspiration $\left(\mathrm{ET}_{\mathrm{o}}\right)$ and crop evapotranspiration for the export and import agriculture products of Ceará trade balance (1997-2012) are shown in Table 4.

Among the exportable crops, cashew nuts have the lowest application rate of fertilizers, insecticides and pesticides ( $22 \mathrm{~kg} / \mathrm{ha}$ ). Although the corresponding reference evapotranspiration $\left(\mathrm{ET}_{\mathrm{o}}\right)$ is close to the reference evapotranspiration of the other crops, its low crop coefficient $\left(K_{\mathrm{c}}=0.55\right)$ causes lower evapotranspiration losses. However, low productivity (only $0.3 \mathrm{t} / \mathrm{ha}$ ) implies extensive farming areas.

\subsection{Water footprints accounting}

The methodology for calculating each component of the water footprint is summarized, and the water footprint patterns of the selected products were quantified according to The Water Footprint Assessment Manual [7].

Table 3: Ceará exports and imports (1997-2012). Producing municipalities, type of agriculture and method of meeting the water needs for each product.

\begin{tabular}{|c|c|c|c|}
\hline Exported product & Municipality & Agriculture & Water supply method \\
\hline Fresh or dried pineapple & Icapuí & Temporary & Rainfed farming and irrigation \\
\hline Fresh or dried banana & Limoeiro do Norte & Permanent & Rainfed farming and irrigation \\
\hline Banana, fresh or dried, other than plantain & Limoeiro do Norte & Permanent & Rainfed farming and irrigation \\
\hline Cashew nuts, fresh or dried, shelled & Beberibe & Permanent & Rainfed farming and irrigation \\
\hline Fresh or dried mango & Varjota & Permanent & Rainfed farming and irrigation \\
\hline Fresh papaya & Mauriti & Permanent & Rainfed farming and irrigation \\
\hline Fresh watermelon & Icapuí & Temporary & Irrigation \\
\hline Fresh melon & Icapuí & Temporary & Irrigation \\
\hline Imported product & Municipality & Agriculture & Water supply method \\
\hline Cotton, threshed, not carded or combed & Iguatu & Temporary & Rainfed farming \\
\hline Cotton, unthreshed, not carded or combed & Iguatu & Temporary & Rainfed farming \\
\hline Cotton (other types), not carded or combed & Iguatu & Temporary & Rainfed farming \\
\hline Semimilled rice, etc., not parboiled, polished, burnished & Morada Nova & Temporary & Irrigation \\
\hline Semimilled rice, etc., parboiled, polished or burnished & Morada Nova & Temporary & Irrigation \\
\hline Cashew nuts, fresh or dried, in shell & Beberibe & Permanent & Rainfed farming and irrigation \\
\hline Dried coconut, shelled, grated or not & Trairi & Permanent & Rainfed farming and irrigation \\
\hline Maize grain, other than for sowing & Muriti & Temporary & Rainfed farming \\
\hline Durum wheat, other than for sowing & Santa Quitéria & Temporary & Rainfed farming \\
\hline Wheat (other than durum or sowing wheat) and wheat with rye & Meruoca & Temporary & Rainfed farming \\
\hline Other wheats and mixtures of wheat and rye, other than for sowing & Meruoca & Temporary & Rainfed farming \\
\hline Other common beans, black, dried, in grains & Meruoca & Temporary & Rainfed farming \\
\hline
\end{tabular}

Source: [6,9-15]. 
Table 4: Ceará's export and import products (1997-2012). Crop productivity (Prod), crop planting and harvesting period, application rate of fertilizer, pesticides, and insecticides per unit area of product $(\mathrm{FR})$, crop coefficient $\left(K_{\mathrm{c}}\right)$, reference evapotranspiration $\left(\mathrm{ET}_{\mathrm{o}}\right)$ and crop evapotranspiration.

\begin{tabular}{|c|c|c|c|c|c|c|c|}
\hline \multirow[b]{2}{*}{ Exported product } & \multirow{2}{*}{$\begin{array}{l}\text { Prod } \\
(\mathrm{t} / \mathrm{ha})\end{array}$} & \multicolumn{2}{|c|}{ Planting and harvesting } & \multirow{2}{*}{$\begin{array}{c}\mathrm{FR} \\
(\mathrm{kg} / \mathrm{ha})\end{array}$} & \multirow[b]{2}{*}{$\mathrm{K}_{\mathrm{c}}$} & \multirow{2}{*}{$\begin{array}{l}\mathrm{Et}_{\mathrm{o}} \\
(\mathrm{mm})\end{array}$} & \multirow{2}{*}{$\begin{array}{c}\mathrm{Et}_{\mathrm{c}} \\
(\mathrm{mm})\end{array}$} \\
\hline & & Period & $\begin{array}{l}\text { Duration } \\
\text { (days) }\end{array}$ & & & & \\
\hline Fresh or dried pineapple & 60.1 & $\begin{array}{c}\text { March to April of the } \\
\text { next year }\end{array}$ & 420 & 80 & 0.88 & 5.2 & 4.57 \\
\hline Fresh or dried banana & 23 & Permanent & 365 & 100 & 0.96 & 5.6 & 5.36 \\
\hline Banana, fresh or dried, other than plantain & 23 & Permanent & 365 & 100 & 0.96 & 5.6 & 5.36 \\
\hline Cashew nuts, fresh or dried, shelled & 0.3 & Permanent & 365 & 22 & 0.55 & 5.2 & 2.85 \\
\hline Fresh or dried mango & 55.7 & Permanent & 365 & 240 & 0.91 & 5 & 4.59 \\
\hline Fresh papaya & 16.5 & Permanent & 365 & 118 & 0.71 & 4.7 & 3.34 \\
\hline Fresh watermelon & 37.8 & August to October & 75 & 102 & 1.1 & 5.2 & 5.71 \\
\hline Fresh melon & 28.3 & August to October & 65 & 50 & 1.06 & 5.2 & 5.5 \\
\hline \multirow[b]{2}{*}{ Imported product } & \multirow{2}{*}{$\begin{array}{l}\text { Prod } \\
(\mathrm{t} / \mathrm{ha})\end{array}$} & \multicolumn{2}{|c|}{ Planting and harvesting } & \multirow{2}{*}{$\begin{array}{c}\mathrm{FR} \\
(\mathrm{kg} / \mathrm{ha})\end{array}$} & \multirow[b]{2}{*}{$\mathrm{K}_{\mathrm{c}}$} & \multirow{2}{*}{$\begin{array}{c}\mathrm{Et}_{\mathrm{o}} \\
(\mathrm{mm})\end{array}$} & \multirow{2}{*}{$\begin{array}{c}\mathrm{Et}_{\mathrm{c}} \\
(\mathrm{mm})\end{array}$} \\
\hline & & Period & $\begin{array}{l}\text { Duration } \\
\text { (days) }\end{array}$ & & & & \\
\hline Cotton, threshed, not carded or combed & 1.34 & January to April & 102 & 210 & 1.12 & 4.62 & 5.17 \\
\hline Cotton, unthreshed, not carded or combed & 1.34 & January to April & 102 & 210 & 1.12 & 4.62 & 5.17 \\
\hline Cotton (other types), not carded or combed & 1.34 & January to April & 102 & 210 & 1.12 & 4.62 & 5.17 \\
\hline Semimilled rice, etc., not parboiled, polished, burnished & 6.18 & August to November & 114 & 120 & 1.2 & 5.58 & 6.7 \\
\hline Semimilled rice, etc., parboiled, polished or burnished & 6.18 & August to November & 114 & 120 & 1.2 & 5.58 & 6.7 \\
\hline Cashew nuts, fresh or dried, in shell & 0.26 & Permanent & 365 & 22 & 0.55 & 5.19 & 2.85 \\
\hline Dried coconut, shelled, grated or not & 7.89 & Permanent & 365 & 90 & 1.01 & 5.11 & 5.16 \\
\hline Maize grain, other than for sowing & 2.02 & January to April & 120 & 40 & 1.05 & 4.71 & 4.95 \\
\hline Durum wheat, other than for sowing & 0.8 & February to April & 80 & 100 & 1.01 & 5.04 & 5.09 \\
\hline Wheat (other than durum or sowing wheat) and wheat with rye & 1.51 & February to May & 115 & 119 & 0.95 & 5.04 & 4.79 \\
\hline Other wheats and mixtures of wheat and rye, other than for sowing & 1.51 & February to May & 115 & 119 & 0.95 & 5.04 & 4.79 \\
\hline Other common beans, black, dried, in grains & 1.51 & February to May & 115 & 119 & 0.95 & 5.04 & 4.79 \\
\hline
\end{tabular}

Source: [6,9-16].

The green component of the water footprint is the volume of rainwater consumed during the production process. This is particularly relevant for agricultural and forestry products, where it refers to the total rainwater evapotranspiration plus the water incorporated into the harvested crop or wood. The green water footprint was determined by eqn (1):

$$
W F_{\text {green }}=\frac{10 x \sum_{d=1}^{d g p} E T_{\text {green }}}{P},
$$

where $W F_{\text {green }}$ is the green water footprint pattern $\left(\mathrm{m}^{3} / \mathrm{t}\right) ; 10$ is a dimensionless factor that converts water height $(\mathrm{mm})$ into volume per unit area $\left(\mathrm{m}^{3} / \mathrm{ha}\right) ; E T_{\text {green }}$ is the green evapotranspiration of the crop ( $\mathrm{mm} /$ day), which is accumulated from the day of planting, $d=1$, until the end of the growth period, $\operatorname{dgp}$ (days); and $P$ is the crop productivity (t/ha).

$E T_{\text {green }}$ is given by the minimum value of the crop evapotranspiration, $E T_{\mathrm{c}}(\mathrm{mm} / \mathrm{day})$, and the effective rainfall, EP (mm/day) (eqn 2). Green evapotranspiration is zero for irrigated crops [17]:

$$
E T_{\text {green }}=\min \left(E T_{c}, \mathrm{EP}\right)
$$


The blue component of the water footprint is an indicator of consumptive use of so-called blue water, in other words, fresh surface or groundwater. Eqn (3) was used to quantify the blue water footprint:

$$
W F_{\text {blue }}=\frac{10 x \sum_{d=1}^{d g p} E T_{\text {blue }}}{P}
$$

where the new variables refer to the blue water footprint pattern, $W F_{b l u e}\left(\mathrm{~m}^{3} / \mathrm{t}\right)$, and to the evapotranspiration based on blue water, $E T_{\text {blue }}(\mathrm{mm} /$ day), which is also cumulative for the previously specified period.

$E T_{\text {blue }}$ is given by the maximum value between zero and the difference between the crop evapotranspiration and effective rainfall (eqn 2). If the effective rainfall is greater than the evapotranspiration of the crop (for example, in rainfed farming), the blue evapotranspiration is zero [17]:

$$
E T_{\text {blue }}=\max \left(0, E T_{c}-E P\right) \text {. }
$$

The grey component of the water footprint is an indicator of the degree of freshwater pollution that can be associated with the process. It is defined as the volume of freshwater that is required to assimilate the load of pollutants based on natural background concentrations and existing ambient water quality standards. The grey water footprint was calculated according to eqn (5):

$$
W F_{\text {grey }}=\frac{(\alpha x T A) \mid\left(c_{\text {max }}-c_{\text {nat }}\right)}{P},
$$

where $W F_{\text {grey }}$ is the grey water footprint pattern $\left(\mathrm{m}^{3} / \mathrm{t}\right) ; \alpha$ is the leaching fraction (dimensionless); $T A$ is the application rate of fertilizers, insecticides or pesticides $(\mathrm{kg} / \mathrm{ha}) ; c_{\max }$ and $c_{\text {nat }}$ are the maximum admissible and natural concentrations of the pollutant in the receiving water medium, respectively; and $P(\mathrm{t} / \mathrm{ha})$ has the previously presented meaning.

The total water footprint, $W F_{\text {total }}\left(\mathrm{m}^{3} / \mathrm{t}\right)$, is the sum of the green, blue and grey components of the entire crop growth process, according to eqn (6):

$$
W F_{\text {total }}=W F_{\text {green }}+W F_{\text {blue }}+W F_{\text {grey }}
$$

The rainfall data were provided by FUNCEME, and there were weather stations in all the selected municipalities. The average daily rainfall refers to the 16 years studied. Each crop has a specific growth period, and for the purpose of supplying the water need, the rainfall that actually occurred during this period was considered.

The reference evapotranspiration for each crop, ET, was calculated using the PenmanMonteith method [18], which is based on the combined effect of the convective transport of air masses and net radiation, and requires data on temperature, humidity, insolation, wind speed, soil, as well as crop characteristics. These data were obtained from the INMET weather stations located in each of the municipalities selected as the main producer of a given crop. If there was no weather station located there, the data from the nearest station were used. The selected weather stations are in the following cities (the municipalities are identified between brackets): Beberibe (Jaguaruana), Icapuí (Jaguaruana), Iguatu (Iguatu), Limoeiro do Norte (Morada Nova), Mauriti (Barbalha), Meruoca (Sobral), Morada Nova (Morada Nova), Santa Quitéria (Sobral), Trairi (Acaraú) and Varjota (Sobral). For each municipality, the average 
annual reference evaporation was calculated multiplying the reference evapotranspiration by the applicable crop coefficient, according to eqn (7):

$$
E T_{c}=K_{c} x E T_{o}
$$

where $E T_{\mathrm{c}}$ is the crop evapotranspiration $(\mathrm{mm}) ; K_{\mathrm{c}}$, the crop coefficient (dimensionless); and $E T_{\text {o }}$ is the reference evapotranspiration $(\mathrm{mm})$.

The water footprint volume of a product was obtained by multiplying the consumption pattern of the water footprint by the quantity exported or imported, according to eqn (8):

$$
W F_{\text {exp } / i m p}=W F_{\text {total }} \times Q_{\text {exp } / i m p}
$$

where $W F_{\text {exp/imp }}$ is the total volume, exported or imported, of the water footprint per product (1); $W F_{\text {total }}$ is the total water footprint of the exported or imported product $(1 / \mathrm{kg})$; and $Q_{\text {exp/imp }}$ is the exported or imported quantity of that product $(\mathrm{kg})$.

For the calculation of the trade balance of virtual water in Ceará, the exported virtual water was subtracted from the imported water; thus, there is surplus (export higher than import) or deficit (import higher than export) when this balance is positive or negative, respectively.

\section{RESULTS}

\subsection{Water footprint in export agriculture products}

The present study shows that green water is by far the largest share of virtual water embodied in exportable agricultural products from Ceará State during the period 1997-2012. As shown in Table $5,71.5 \%$ of the virtual water required to produce those products is green (rainfed agriculture). Essentially, this green water is soil moisture and is not available for other forms of consumption.

Figure 2 illustrates the percentage of green, blue and grey from the total water footprint of each crop of the export agenda. The water footprint of each colour depends on the crop type, the water supply method and the site of production, particularly in terms of soil and climate.

As can be seen, the crops that consume more blue water (in \% from the total water footprint) are melon, watermelon, and banana (in that order). Melon, in addition to have the greatest percentage of blue water footprints, also has a great percentage of grey water footprint, which indicates the use of fertilizers, pesticides, and insecticides in its production, contributing to water contamination of the basin where it is grown. Cashew nuts, pineapple and papaya (in that order) are the crops that consume more green water.

Especial attention should be given to cashew nuts. Ceará accounts for $80 \%$ of all Brazilian cashew nuts exports, and in 2011 Brazil was the fifth-largest producer and the thirdlargest exporter of this crop worldwide [6]. In the present study, cashew nuts presented the highest total water footprint, corresponding to $99.1 \%$ (Table 5) of all virtual water exported in agricultural products. From this total, $72 \%$ is from rain (green water), $25.9 \%$ comes from irrigation (blue water) and $2.1 \%$ is grey water, which means that the percentage use of water from irrigation (blue water) to produce cashew nuts in Ceará is higher than the world average [4].

Ceará has a low efficiency in its cashew nut production. An estimated 40,000 1/kg of virtual water is used to produce cashew nuts in Ceará and the corresponding world average is approximately $14,000 \mathrm{l} / \mathrm{kg}$ [4]. 
Table 5: Green, blue, grey and total (WFT) water footprints (WFs) for each export and import agriculture product from or by Ceará (1997-2012).

\begin{tabular}{|c|c|c|c|c|c|c|c|c|}
\hline \multirow[t]{2}{*}{ Exported Product } & \multirow{2}{*}{$\begin{array}{c}\text { Green WF } \\
\text { Consumption } \\
\left(\mathrm{hm}^{3}\right)\end{array}$} & \multicolumn{3}{|c|}{ Blue WF } & \multirow{2}{*}{$\begin{array}{c}\text { Gray WF } \\
\text { Consumption } \\
\left(\mathrm{hm}^{3}\right)\end{array}$} & \multicolumn{3}{|c|}{ Total WF } \\
\hline & & $\%$ & $\begin{array}{c}\text { Consumption } \\
\left(\mathrm{hm}^{3}\right)\end{array}$ & $\%$ & & $\%$ & $\begin{array}{c}\text { Consumption } \\
\left(\mathrm{hm}^{3}\right)\end{array}$ & $\%$ \\
\hline Fresh or dried pineapple & 22.5 & 60.5 & 13.2 & 35.5 & 1.5 & 4,0 & 37.2 & 0.2 \\
\hline Banana, fresh or dried, other than plantain & 6.7 & 33.7 & 12.2 & 61.4 & 1.0 & 4.9 & 19.9 & 0.1 \\
\hline Cashew nuts, fresh or dried, shelled & $13,200.1$ & 72,0 & $4,742.6$ & 25,9 & 378,9 & 2,1 & $18,321.5$ & 99.1 \\
\hline Fresh watermelon & - & 0,0 & 16.2 & 80.8 & 3.9 & 19.2 & 20.0 & 0.1 \\
\hline Fresh melon & - & 0,0 & 110.9 & 87.7 & 15.5 & 12.3 & 126.5 & 0.7 \\
\hline Sum & $13,278.0$ & - & $4,965.6$ & - & 407,9 & - & $18,651.5$ & - \\
\hline$\%$ WFT of all crops & & 71.2 & & 26.6 & & 2.2 & & 100.0 \\
\hline Imported Product & Green WF & & Blue WF & & Gray WF & & Total WF & \\
\hline Cotton, unthreshed, not carded or combed & 1.025 .0 & 71.5 & - & 0 & 407.8 & 28.5 & $1,432.8$ & 2.3 \\
\hline Cotton (other types), not carded or combed & $1,953.9$ & 71.5 & - & 0 & 777.4 & 28.5 & $2,731.4$ & 4.3 \\
\hline Semimilled rice, etc., not parboiled, polished, burnished & - & 0 & 172.9 & 86.4 & 27.2 & 13.6 & 200.1 & 0.3 \\
\hline Semimilled rice, etc., parboiled, polished or burnished & - & 0 & 13.8 & 86.4 & 2.2 & 13.6 & 15.9 & 0 \\
\hline Cashew nuts, fresh or dried, in shell & $3,694.4$ & 72 & $1,327.3$ & 25.9 & 106,0 & 2.1 & $5,127.8$ & 8.1 \\
\hline Dried coconut, shelled, grated or not & 17.4 & 60.1 & 10.2 & 35.3 & 1.3 & 4.6 & 28.9 & 0 \\
\hline Maize grain, other than for sowing & $2,058.2$ & 93.7 & - & 0 & 138.7 & 6.3 & $2,196.9$ & 3.5 \\
\hline Durum wheat, other than for sowing & 40.8 & 80.3 & - & 0 & 10.0 & 19.7 & 50.8 & 0.1 \\
\hline Wheat (other than durum or sowing wheat) and wheat with rye & 98,1 & 82.2 & - & 0 & 20.8 & 17.8 & 116.8 & 0.2 \\
\hline Other wheats and mixtures of wheat and rye, other than for sowing & $39,090.1$ & 82.2 & - & 0 & $8,448.2$ & 17.8 & $47,538.3$ & 75.1 \\
\hline Other common beans, black, dried, in grains & $3,090.7$ & 82.2 & - & 0 & 668.0 & 17.8 & $3,758.7$ & 5.9 \\
\hline Sum & $51,125.7$ & - & $1,524.3$ & - & $10,631.1$ & - & $63,281.1$ & \\
\hline$\%$ WFT of all crops & & 80.8 & & 2.4 & & 16.8 & & 100.0 \\
\hline
\end{tabular}

Source: Based on data from [6,9-16,19-22].

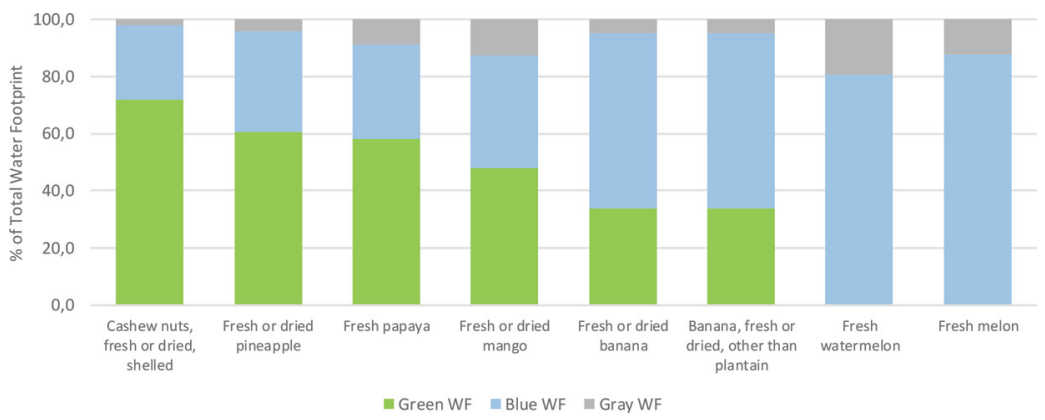

Figure 2: Green, blue, grey percentage of total water footprints (WFs) for each agriculture product exported by Ceará (1997-2012).

Given the high virtual water consumption of cashew nuts produced in Ceará (in $1 / \mathrm{kg}$ ), the large quantities produced (in $\mathrm{kg}$ ), and due to its economic importance for the state the cashew nut accounts for $16.4 \%$ of total State's exports (measured in monetary terms) - Ceará's water resources managers could study reducing the cashew nuts' blue footprint by encouraging rainfed agriculture (green water). During 1997-2012 period, the virtual blue water exported embedded in this product was estimated at $4,742.6 \mathrm{hm}^{3}$. 


\subsection{Water footprint in agriculture import products}

As shown in Table 5, Ceará imported $63,281.1 \mathrm{hm}^{3}$ of total virtual water in the 16 years analysed. It is important to stress that Ceará faces recurrent water shortages; therefore, importing such volume of virtual water is aligned with state water policy.

Wheat was the largest agricultural import, with $75.1 \%$ of the total water footprint of the agricultural basket (Table 5). From this total, $82.2 \%$ is green water, which means that according to the consumption approach if this crop was produced in Ceará, the source of water would be the rain. It would not have consumed water from the reservoirs (blue water); but it would have required about $8,448.2 \mathrm{hm}^{3} /$ year to dilute the fertilizers, insecticides, and pesticides used in its production (grey water).

According to the study, the consumption pattern of wheat grown in Ceará was estimated at approximately 4,400 liters $/ \mathrm{kg}$ that is almost 2.5 times the world average, meaning that, from the point of view of water resources, it is more efficient to import than to produce wheat.

Figure 3 illustrates the percentage of green, blue and grey from the total water footprint of each crop of the import basket. Rice is a good option to import. As it is irrigated by flooding, such a product would consume blue water (approximately $187 \mathrm{hm}^{3}$, in Table 5) if it had been grown in Ceará, given the high evaporative capacity of this region. The water footprint is not much higher because the imported quantity of the product was low: approximately $150 \mathrm{t}$ (for instance, wheat imports amounted to almost 11,000 t).

\subsection{Virtual water trade balance}

The result of the virtual water trade balance of the state of Ceará (1997-2012) was -44,629.6 hm (green water $-37,847.7 \mathrm{hm}^{3}$, blue water $3,441.3 \mathrm{hm}^{3}$, and grey water $-10,223.2 \mathrm{hm}^{3}$ ). Negative values mean that Ceará imported more than it exported. In regions plagued by droughts, having greater imports indicates good water resources management practices.

Figure 4 shows that the trade balance of total virtual water, green and grey was always negative, meaning that Ceará imported more than it exported, which is expected given the state's water-scarce condition. However, except for 2011 and 2012, the blue water trade balance is always positive, meaning that Ceará is exporting water from its reservoirs. In the general calculation, the total volume of virtual water imported was $239.3 \%$ higher than the volume exported.

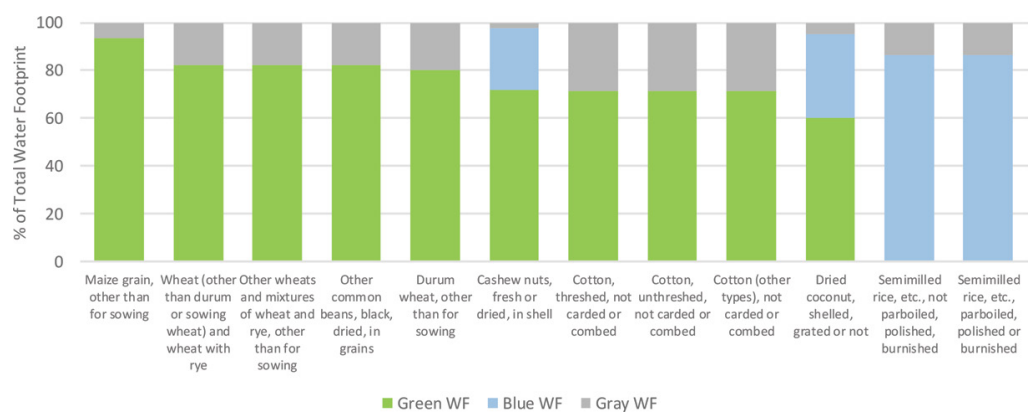

Figure 3: Percentage of total green, blue, grey water footprints (WFs) for each imported agriculture product from Ceará (1997-2012). 


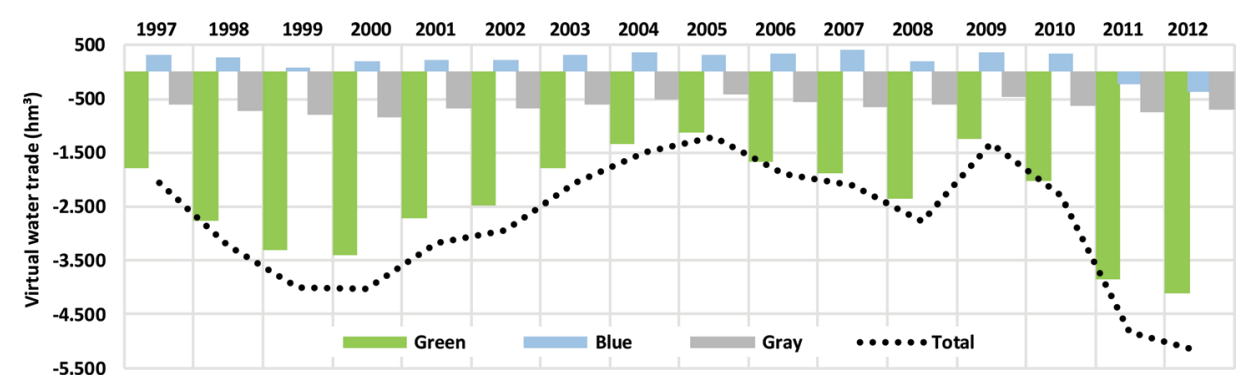

Figure 4: Ceará's virtual water trade balance (1997-2012).

\section{CONCLUSIONS}

This study analysed whether the international trade policy of agricultural products is aligned with the water resources policy of Ceará. This state is plagued by chronic water scarcity but needs to develop economically and agricultural products account for a significant share of Ceará's total trade balance.

As far as exports are concerned, cashew nuts deserve special attention for at least two reasons. First, the total water footprint of cashew nuts is the highest amongst the exports analysed. Second, cashew nuts are exported in large quantities (Table 5) - the largest of all exported agricultural products. Almost all $(99.1 \%)$ virtual water exported in agricultural products by Ceará is derived from the production chain of this crop. Fortunately, $72 \%$ of the virtual water required for cashew nut production comes directly from rain (rainfed farming), and it does not produce much pollution load (its grey water footprint is only $2.1 \%$ of its total water footprint). It means that about $71 \%$ of exported virtual water come from the fixed water system (green water). This use can be considered sustainable and profitable at the same time.

Despite being environmentally sustainable, it would still be possible to argue that the amount of blue water used is enormous. Blue water required for cashew nut production $(25.6 \%)$ is impressive (equivalent to $4,742.6 \mathrm{hm}^{3}$ in 16 years). Such quantity of water use calls for an investigation on how to reduce it. A challenge for sustainability is to transfer the use of blue water to green water.

Fresh melon export also stands out, being the second largest total water footprint (Table 5). The present study pointed out that melon, in addition to having the second highest blue water footprint, also has a significant grey water footprint, contributing to the contamination of the water resources where it is grown. From the perspective of virtual water footprint, melon cultivation for export should not be promoted. Import of rice, high-water consumer crop, is also profitable in terms of virtual water.

A calculation of the combined exports and imports showed that, between 1997 and 2012, the net virtual water trade balance was $44,629.6 \mathrm{hm}^{3}$. Throughout that period, the trade balance of total, green and grey virtual water was always negative, which means that Ceará is a net importer of virtual water, which is consistent with its water-scarce condition. The total import volume of virtual water was $239.3 \%$ higher than the volume exported. This can be considered sustainable.

Additionally, the water footprint assessment proved to be a useful tool that gives greater transparency to import and export product choices while giving a new dimension to a water resources policy by warning that such a policy must be considered together with a region or country's other public policies (including commercial policies). 
Water footprint would also be an important instrument to water demand management because it allows society to identify sensitive consumption categories. Labelling or higher pricing blue water intensive products can help improving sectoral water efficiency as well as directing users' choices towards lower water intensive goods and services. Additionally, higher prices for water can stimulate the import of water intensive goods and reduce the stress on water resources. However, it has social implications and should be carefully evaluated.

\section{REFERENCES}

[1] Allan J.A., Fortunately there are substitutes for water otherwise our hydro-political futures would be impossible. ODA, Priorities Water Resources Allocation Management, London: ODA, p. 13-26, 1993.

[2] Hoekstra A. \& Hung P.Q., Virtual Water Trade: A Quantification of Virtual Water Flows between Nations in Relation to International Crop Trade, vol. 49. Delft: UNESCO-IHE Institute for Water Education, 2002.

[3] Fan X, Li X, Yin J, Liang J., Temporal characteristics and spatial homogeneity of virtual water trade: a complex network analysis. Water Resources Management, 33, pp. 1467-80, 2019. https://doi.org/10.1007/s11269-019-2199-2.

[4] Mekonnen MM, Hoekstra AY., The green, blue and grey water footprint of crops and derived crop products. Hydrol Earth Syst Sci, 15:1577-600, 2011. https://doi.org/10.5194/ hess-15-1577-2011.

[5] Qasemipour E, Abbasi A., Virtual water flow and water footprint assessment of an arid region: a case study of South Khorasan province, Iran. Water (Switzerland), 11, 2019. https://doi.org/10.3390/w11091755.

[6] MDIC., Comércio Exterior. Ministério Do Desenvolvimento, Indústria e Comércio Exterior Gov Do Bras Secr Comércio Exter (Secex) 2018. http://www.desenvolvimento.gov.br (accessed October 23, 2018).

[7] Hoekstra AY., The global dimension of water governance: why the river basin approach is no longer sufficient and why cooperative action at global level is needed. Water (Switzerland), 3:21-46, 2011. https://doi.org/10.3390/w3010021.

[8] Chapagain AK, Hoekstra AY., Virtual water flows between nations in relation to trade in livestock and livestock products. 2003.

[9] CONAB., Produtos e serviços: indicadores da agropecuária. Cia Nac Abastecimento Gov Do Bras Ministério Da Agric Pecuária e Abast 2018. http://www.conab.gov.br (accessed October 20, 2018).

[10] EMATERCE., Publicações. Empres Assist Técnica e Extensão Rural Do Ceará Gov Do Estado Do Ceará Secr Do Desenvolv Agrário 2018. https://www.ematerce.ce.gov.br (accessed October 13, 2018).

[11] EMBRAPA. Agricultura. Empres Bras Pesqui Agropecuária Gov Do Bras Ministério Da Agric Pecuária e Abast 2018. http://www.embrapa.br (accessed October 11, 2018).

[12] IBGE., Banco de dados. Inst Bras Geogr e Estatística Gov Do Bras Ministério Do Planejamento, Orçamento e Gestão 2018. http://www.ibge.gov.br/home (accessed October 19, 2018).

[13] IPECE., Banco de dados: CIPP. Inst Pesqui e Estratégia Econômica Do Ceará Gov Do Estado Do Ceará Secr Do Planej e Gestão 2018. http://www.ipece.ce.gov.br (accessed October 13, 2018). 
[14] MAPA., Vegetal. Ministério Da Agric Pecuária e Abastecimento Gov Do Bras 2018. http://www.agricultura.gov.br (accessed November 13, 2018).

[15] SDA., Informações e serviços. Secr Do Desenvolv Agrário Do Estado Ceará Gov Do Estado Do Ceará 2018. http://www.sda.ce.gov.br (accessed October 20, 2018).

[16] INMET., Estações e dados. Inst Nac Meteorol Gov Do Bras Ministério Da Agric Pecuária e Abastecimento 2018. http://www.inmet.gov.br (accessed October 13, 2018).

[17] Chapagain AK, Hoekstra AY., The blue, green and grey water footprint of rice from production and consumption perspectives. Ecol Econ, 70:749-58, 2011. https://doi. org/10.1016/j.ecolecon.2010.11.012.

[18] Allen RG, Pereira LS, Raes D, Smith M. FAO Irrigation and Drainage Paper n 56 (Crop Evaporation - Guidelines for computing crop water requirements). Rome: 1998.

[19] ADECE., Setores da economia. Agência Do Desenvolv Do Estado Do Ceará Gov Do Estado Do Ceará Cons Estadual Desenvolv Econômico 2018. http://www.adece.ce.gov. br (accessed August 21, 2018).

[20] ADAGRI., Defesa vegetal. Agência Def Agropecuária Do Estado Do Ceará Gov Do Estado Do Ceará Secr Do Desenvolv Agrário 2018. https://www.adagri.ce.gov.br (accessed July 20, 2018).

[21] FUNCEME. Tempo: download das séries históricas. Fundação Cear Meteorol e Recur Hídricos Gov Do Estado Do Ceará Secr Da Ciência, Tecnol e Educ Super 2018. http:// www.funceme.br (accessed October 13, 2018).

[22] EPA., Drinking water contaminants. Environ Prot Agency 2018. https://www.epa.gov/ safewater/mcl.html\#1 (accessed October 29, 2018). 